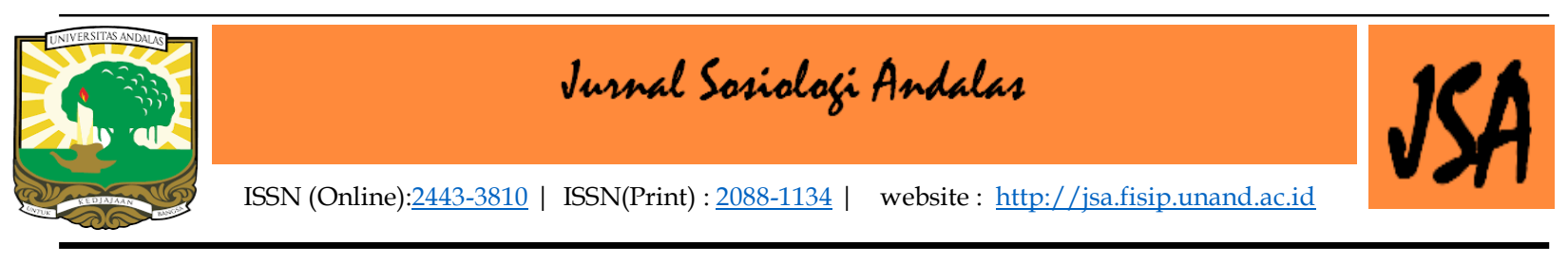

\title{
Perbedaan Perilaku Masyarakat tentang Pengelolaan Sampah Rumah Tangga Terhadap Pemberian Penyuluhan
}

\author{
Nurhayati, Oktavianis, Cici Apriza Y, Budi Dwi Satria \\ Universitas Fort De Kock Bukittinggi
}

Email: nurhayati@fdk.ac.id

\begin{abstract}
Abstrak: Looking at population growth in Indonesia, it certainly has a significant effect on the issue of waste generation, where the number of waste generation from 2015-2019 has always increased, as well as Tanah Datar District, which has a large amount of waste generation, reaching 133.66 ton per day. Therefore, counseling is an important effort to do in order to manage household waste. The purpose of this study was to look at The Effectiveness of Counselling on Community Behavior Related to Household Waste Management in Kenagarian Baringin Tanah Datar. This study used Quasi Experiment Design method. The samples were 16 respondents. They were divided into 2 groups. The first group was given counseling through audio visual media and the other given counseling through leaflet media. The data were collected through questionnaire. Then, it was processed by reducing, presenting and drawing conclusions. Last, the data were analyzed by Paired Sample T Test and the Independent T-Test. The results of this study showed that the audio visual and leaflet media were increase respondents' knowledge ( $p=0.0005$ and 0.0005$)$, attitudes $(p=0.0005$ and 0.0005$)$ and actions $(p=0.0005$ and 0,0005). Moreover, there was no difference increasing of mean of the knowledge, attitudes and actions of audio visual media group with the leaflet media group ( $p=0.751,0.519$ and 0.727$)$. In short, it can be concluded that audio visual media and leaflets were effective for health promotion. Then, it is suggested to the public always manage household waste properly. Next, it is better for the health workers to provide counseling and supervision of environmental health on a regular basis.
\end{abstract}

Keywords: Waste Management, Knowledge, Attitudes, Actions.

\section{A. PENDAHULUAN}

Lingkungan adalah segala sesuatu yang ada di sekitar manusia yang mempengaruhi perkembangan kehidupan manusia baik langsung maupun tidak langsung. Lingkungan yang diharapkan untuk mewujudkan mutu kehidupan yang sehat adalah lingkungan yang kondusif bagi terwujudnya keadaan sehat fisik, mental, sosial, dan spiritual dan lingkungan tersebut mencakup unsur fisik, biologis, dan psikologis. (Nurafiyani, 2010). Persoalan sampah merupakan konsekuensi nyata dari aktivitas yang dilakukan manusia dalam kehidupannya, karena hampir seluruh kegiatan manusia akan meninggalkan sisa atau bekas yang disebut dengan sampah. Salah satu dampak akibat laju pertumbuhan penduduk adalah meningkatnya volume sampah yang diproduksi. Pengolahan sampah yang dilakukan selama ini belum sesuai dengan metoda dan teknik pengolahan sampah yang berwawasan lingkungan sehingga menimbulkan dampak negatif terhadap kesehatan masyarakat dan juga lingkungan.meningkat tiga kali lipat menjadi 3,6 juta per tahun. 
Jumlah penduduk yang besar dengan tingkat pertumbuhan yang tinggi mengakibatkan bertambahnya volume timbulan sampah. Di samping itu, pola konsumsi masyarakat memberikan kontribusi besar dalam menimbulkan jenis sampah yang semakin beragam, antara lain, sampah kemasan yang berbahaya atau sulit diurai oleh proses alam. Penanganan dan pengendalian akan menjadi semakin kompleks dan rumit dengan semakin kompleksnya jenis maupun komposisi dari sampah sejalan dengan semakin majunya kebudayaan. (Djunaidi, 2017).

Sampah menjadi salah satu permasalahan yang dialami oleh berbagai negara di dunia karena sifatnya yang sulit diurai, namun keberadaannya semakin meningkat setiap tahun. Masing-masing negara memiliki jumlah sampah yang berbeda dengan berbagai latar belakang penduduk dan kondisi negaranya. Berikut ini beberapa angka tentang plastik yang didapat dari Our World in Data. Berdasarkan data dari ScienceMag, jumlah produksi sampah plastik global sejak 1950 hingga 2015 cenderung selalu menunjukkan peningkatan. Pada 1950, produksi sampah dunia ada di angka 2 juta ton per tahun. Sementara 65 tahun setelah itu, pada 2015 produksi sampah sudah ada di angka 381 juta ton per tahun. Angka ini meningkat lebih dari 190 kali lipat, dengan rata-rata peningkatan sebesar 5,8 ton per tahun. (Our World in Data, 2015) Melihat dari pertumbuhan penduduk di Indonesia, tentu sangat berpengaruh terhadap persoalan timbulan sampah. Dimana jumlah tingkat timbulan sampah di Indonesia mengalami ke naikan dari tahun 2015 sampai dengan tahun 2018, yakni pada tahun 2015 sebanyak 64.400 .000 ton per tahun, 2016 sebanyak 65.200.000 ton per tahun, 2017 sebanyak 65.800 .000 ton per tahun, dan pada tahun 2018 sebanyak 66.500.000 ton per tahun. Kenaikan jumlah timbulan ini sangat tidak sebanding dengan jumlah capaian pengurangan timbulan sampah, yakni pada tahun 2018 hanya mencapai 1.503.635 ton per tahun atau hanya (2.26 persen) dari jumlah timbulan sampah di Indonesia. (KementerianLingkungan Hidup dan Kehutanan RI, 2018).

Demikian pada Provinsi Sumatera Barat, persoalan sampah cukup menjadi salah satu permasalahan yang serius, yakni permasalahan tersebut disebabkan oleh jumlah pada timbulan sampah di Sumatera Barat dari tahun ke tahunnya selalu mengalami kenaikan hingga pada tahun 2017 sudah mencapai 2.392 ton per hari. Pencapaian timbulan sampah tersebut sangat di pengaruhi oleh pengetahuan atau kurangnya kesadaran masyarakat dan sarana prasarana yang tersedia. Hal ini tentu dapat menimbulkan permasalahan lingkungan yang cukup serius apabila tidak ditangani dengan cepat. (Dinas Lingkungan Hidup Sumbar, 2017).

Seperti halnya di Kabupaten Tanah Datar yang salah satu Kab/Kota yang biasa di kenal sebagai Kota Budaya yang terletak di provinsi Sumatera Barat, Kabupaten ini juga termasuk ke dalam jumlah penduduk yang terbanyak di Provinsi Sumatera Barat, berdasarkan hasil proyeksi (Badan Pusat Statistik Kabupaten Tanah Datar), jumlah penduduk pada tahun 2018 mencapai 346.560 jiwa, yang tersebar di seluruh nagari atau jorong. Dengan banyaknya penduduk di Kabupaten Tanah Datar ini tentunya juga mengakibatkan banyaknya permasalahan lingkungan, yang terutama sekali yaitu pada permasalahan sampah yang volume timbulan sampah yang besar, yakni mencapai 133.66 ton per hari. Volume timbulan sampah terdiri dari sampah yang di timbun ke TPA sebanyak 34.30 ton per hari, dan sampah yang tidak terkelola sebanyak 99.36 ton per hari. Jenis volume timbulan sampah yang terbanyak di Kabupaten Tanah Datar yaitu berasal dari 
timbulan sampah rumah tangga yakni mencapai 70.85 ton per hari. (KementerianLingkungan Hidup RI, 2018). Dan jumlah timbulan sampah di Tanah Datar yang tercatat terbanyak yaitu pada Kecamatan Limo Kaum yakni mencapai (50.424 L/orang/hari) dengan jumlah penduduk yang terbanyak dari kecamatan kecamatan lainya yaitu sebanyak (39.681 jiwa). (Kantor Lingkungan Hidup Kabupaten Tanah Datar, 2018).

Berdasarkan survey awal yang peneliti lakukan, dari 13 Jorong yang ada di Nagari Baringin, Kecamatan Limo Kaum, Kabupaten Tanah Datar pada 14 November 2018, terdapat 1 Jorong yaitu Jorong Baringin dengan permasalahan pengolahan sampah yang kompleks. Diantaranya adalah pemukiman padat dengan jumlah penduduk yang tebanyak mencapai 2.965 jiwa yang yang tentunya dapat memicu peningkatan produksi sampah di daerah tersebut, kurangnya partisipasi masyarakat untuk melakukan pengolahan sampah dengan baik dan benar, seperti membuang sampah ke aliran sungai, serta kurangnya sarana prasarana seperti TPS dan kurangnya peran serta sektor terkait kesehatan lingkungan tersebut.

\section{B. METODE PENELITIAN}

Jenis penelitian merupakan penelitian (Quasi Eksperiment Design) dengan penelitian membagi sampel menjadi dua kelompok yang di klasifikasikan yaitu kelompok Audiovisual dan kelompok Leaflet Sampel penelitian ini diambil dengan Teknik Purposive Sampling.

\section{HASIL DAN PEMBAHASAN}

\section{A. Analisis Univariat}

1. Penyuluhan kesehatan tentang pengolahan sampah rumah tangga dengan media leaflet.

a. Rata-rata Pengetahuan Sesudah Penyuluhan Pengolahan Sampah Rumah Tangga Menggunakan Media Audio visual

Tabel 1

\begin{tabular}{lcccc}
\hline Pengetahuan Mean & $\begin{array}{c}\text { Standar } \\
\text { Deviasi }\end{array}$ & $\begin{array}{c}\text { Min - } \\
\text { Max }\end{array}$ & N \\
\hline $\begin{array}{c}\text { Post-test } \\
\text { Audio visual }\end{array}$ & 15,75 & 1,581 & $14-18$ & 8 \\
\hline
\end{tabular}

Pada tabel 1 terlihat rata-rata pengetahuan sesudah penyuluhan dengan media Audio visual adalah 15,75 dengan standar deviasi 1,581. Nilai minimum adalah 14 dan nilai maksimum adalah 18.

b. Rata-rata Sikap Sesudah Penyuluhan Pengolahan Sampah Rumah Tangga Menggunakan Media Audio visual

\begin{tabular}{ccccc}
\multicolumn{4}{c}{ Tabel 2 } \\
\hline Sikap & Mean & $\begin{array}{c}\text { Standar } \\
\text { Deviasi }\end{array}$ & $\begin{array}{c}\text { Min - } \\
\text { Max }\end{array}$ & N \\
\hline $\begin{array}{c}\text { Post- } \\
\text { test }\end{array}$ & 58,25 & 3,284 & $52-62$ & 8 \\
$\begin{array}{c}\text { Audio } \\
\text { visual }\end{array}$ & & & & \\
\hline
\end{tabular}


Pada tabel 2 terlihat rata-rata sikap sesudah penyuluhan dengan media Audio visual adalah 58,25 dengan standar deviasi 3,284. Nilai minimum adalah 52 dan nilai maksimum adalah 62 .

c. Rata-rata Tindakan Sesudah Penyuluhan Pengolahan Sampah Rumah Tangga Menggunakan Media Audio visual

Tabel 3

\begin{tabular}{lrrcc}
\hline Tindakan & $\begin{array}{r}\text { Mea } \\
\mathrm{n}\end{array}$ & $\begin{array}{c}\text { Standar } \\
\text { Deviasi }\end{array}$ & $\begin{array}{c}\text { Min - } \\
\text { Max }\end{array}$ & $\mathrm{N}$ \\
\hline $\begin{array}{c}\text { Post- } \\
\text { test }\end{array}$ & & & & 8 \\
$\begin{array}{c}\text { Audio } \\
\text { visual }\end{array}$ & 7,50 & 1,309 & $6-10$ & \\
\hline
\end{tabular}

Pada tabel 3 terlihat rata-rata tindakan sesudah penyuluhan dengan media Audio visual adalah 7,50 dengan standar deviasi 1,309. Nilai minimum adalah 6 dan nilai maksimum adalah 10 .

\section{B. Analisis Bivariat}

1. Penyuluhan Kesehatan Tentang Pengolahan Sampah Rumah Tangga Dengan Media Audio visual

a. Perbedaan Pengetahuan Sebelum dan Sesudah Penyuluhan Dengan Media Audio visual

Tabel 4

\begin{tabular}{|c|c|c|c|c|c|}
\hline \multirow[t]{2}{*}{ Pengukuran } & \multicolumn{2}{|c|}{ Pengetahuan } & \multirow{2}{*}{$\begin{array}{c}\text { Mean } \\
\text { Different }\end{array}$} & \multirow{2}{*}{$\mathrm{N}$} & \multirow[t]{2}{*}{$\begin{array}{c}\mathrm{P} \\
\text { Value }\end{array}$} \\
\hline & Mean & SD & & & \\
\hline $\begin{array}{c}\text { Pre-test Audio } \\
\text { visual }\end{array}$ & 9,62 & $\begin{array}{c}1,92 \\
3\end{array}$ & \multirow{2}{*}{-612} & \multirow{2}{*}{8} & \multirow[t]{2}{*}{0,0005} \\
\hline $\begin{array}{c}\text { Post-test } \\
\text { Audio visual }\end{array}$ & 15,75 & $\begin{array}{c}1,58 \\
1\end{array}$ & & & \\
\hline
\end{tabular}

Berdasarkan table 4 diketahui rata-rata pengetahuan sebelum pelaksanaan penyuluhan dengan media Audio visual adalah 9,62 dengan standar deviasi 1,923. Setelah dilakukan penyuluhan dengan media Audio visual diperoleh rata-rata pengetahuan adalah 15,75 dengan standar deviasi 1,581. Perbedaan kedua variabel adalah $-6,12$.

Hasil uji statistik diperoleh p Value $=0,0005<0,05$ artinya Ho ditolak. Dapat disimpulkan bahwa terdapat perbedaan yang sangat signifikan terhadap nilai pengetahuan sebelum dan sesudah.

Penelitian ini sejalan dengan penelitian yang dilakukan oleh Meidiana,dkk (2018) tentang "Pengaruh Edukasi melalui Media Audio Visual terhadap Pengetahuan dan Sikap Remaja Overweight" yang menunjukkan rata-rata pengetahuan sebelum diberikan penyuluhan adalah 8,60 dan standar deviasi 1,482, sedangkan rata-rata pengetahuan setelah diberikan penyuluhan 9,48 dan standar deviasi 1,012, sehingga didapatkan selisih rata-rata sebelum dan sesudah 
penyuluhan adalah 1,24 . Hasil uji statistik menunjukkan $\mathrm{p}$ value $=0,000$ dimana terdapat perbedaan nilai rata-rata yang signifikan antara sebelum dengan sesudah dilakukan penyuluhan dengan media audio visual.

Dari penelitian dan peneliti sebelumnya lakukan, peneliti berasumsi bahwa adanya perbedaan rat-rata pengetahuan sebelum dan sesudah diberikan penyuluhan dengan media audio visual adalah karena adanya video dan audio yang menarik perhatian responden, yang membuat responden fokus terhadap materi yang disampaikan, sehingga proses penyerapan informasi akan lebih mudah diperoleh. Cara penyampaian informasi yang kaku dan dianggap kurang menarik akan mengurangi minat responden dalam menyerap informasi, sehingga proses penyuluhan menjadi tidak efektif

b. Perbedaan Sikap Sebelum dan Sesudah Penyuluhan Dengan Media Audio visual

\section{Tabel 5}

\begin{tabular}{|c|c|c|c|c|c|}
\hline \multirow[t]{2}{*}{ Pengukuran } & \multicolumn{2}{|c|}{ Sikap } & \multirow{2}{*}{$\begin{array}{c}\text { Mean } \\
\text { Different }\end{array}$} & \multirow{2}{*}{$\mathrm{N}$} & \multirow[t]{2}{*}{$\begin{array}{c}\mathrm{P} \\
\text { Value }\end{array}$} \\
\hline & Mean & $\begin{array}{l}S \\
D\end{array}$ & & & \\
\hline $\begin{array}{c}\text { Pre-test Audio } \\
\text { visual }\end{array}$ & 43,75 & $\begin{array}{r}2,7 \\
65\end{array}$ & $-14,50$ & 8 & 0,0005 \\
\hline $\begin{array}{c}\text { Post-test } \\
\text { Audio visual }\end{array}$ & 58,25 & $\begin{array}{l}3,2 \\
84 \\
\end{array}$ & & & \\
\hline
\end{tabular}

Berdasarkan tabel 5 diketahui rata-rata sikap sebelum pelaksanaan penyuluhan dengan media Audio visual adalah 43,75 dengan standar deviasi 2,765. Setelah dilakukan penyuluhan dengan media Audio visual diperoleh rata-rata sikap adalah 58,25 dengan standar deviasi 3,284. Perbedaan kedua variabel adalah 14,50 .

Hasil uji statistik diperoleh p Value $=0,0005<0,05$ artinya Ho ditolak. Dapat disimpulkan bahwa terdapat perbedaan yang sangat signifikan terhadap nilai sikapsebelum dan sesudah.

Penelitian ini sejalan dengan penelitian yang dilakukan oleh Meidiana,dkk (2018) tentang "Pengaruh Edukasi melalui Media Audio Visual terhadap Pengetahuan dan Sikap Remaja Overweight" yang menunjukkan rata-rata sikap sebelum diberikan penyuluhan adalah 36,62 dan standar deviasi 3,874, sedangkan rata-rata sikap setelah diberikan penyuluhan adalah 40,38 dan standar deviasi 2,696, sehingga didapatkan selisih rata-rata sebelum dan sesudah penyuluhan adalah 4,24. Hasil uji statistik menunjukkan $\mathrm{p}$ value $=0,001$ dimana terdapat perbedaan nilai rata-rata yang signifikan antara sebelum dengan sesudah dilakukan penyuluhan dengan media audio visual.

Dari hasil penelitian peneliti dan peneliti sebelumnya lakukan, peneliti berasumsi bahwa keberadaan audio visual dapat berdampak baik terhadap perubahan rata-rata sikap responden sebelum dan sesudah dilakukan penyuluhan. Sikap yang sejatinya dapat berubah karena pengaruh lingkungan, juga dapat ditingkatkan dengan mengoptimalkan informasi yang dimiliki. Sikap menunjukkan acceptance individu terhadap informasi yang diterima, apakah individu tersebut menyikapi informasi dengan positif atau tidak. Walaupun seseorang memiliki pengetahuan yang baik namun tidak dibarengi dengan sikap yang baik, maka tidak akan dapat diwujudkan dalam suatu tindakan. 
c. Perbedaan Tindakan Sebelum dan Sesudah Penyuluhan Dengan Media Audio visual

Tabel 6

\begin{tabular}{|c|c|c|c|c|c|}
\hline \multirow[t]{2}{*}{ Pengukuran } & \multicolumn{2}{|c|}{ Tindakan } & \multirow{2}{*}{$\begin{array}{c}\text { Mean } \\
\text { Different }\end{array}$} & \multirow{2}{*}{$\mathrm{N}$} & \multirow[t]{2}{*}{$\underset{\text { Value }}{\mathrm{p}}$} \\
\hline & Mean & SD & & & \\
\hline $\begin{array}{c}\text { Pre-test Audio } \\
\text { visual }\end{array}$ & 4,00 & $\begin{array}{c}1,06 \\
9\end{array}$ & \multirow{2}{*}{$-3,50$} & \multirow{2}{*}{8} & \multirow[t]{2}{*}{0,0005} \\
\hline $\begin{array}{c}\text { Post-test Audio } \\
\text { visual }\end{array}$ & 7,50 & $\begin{array}{c}1,30 \\
9\end{array}$ & & & \\
\hline
\end{tabular}

Berdasarkan tabel 6 diketahui rata-rata tindakan sebelum pelaksanaan penyuluhan dengan media Audio visual adalah 4,00 dengan standar deviasi 1,069. Setelah dilakukan penyuluhan dengan media Audio visual diperoleh rata-rata tindakan adalah 7,50 dengan standar deviasi 1,309, perbedaan kedua variabel adalah $-3,50$. Hasil uji statistik diperoleh $p$ Value $=0,0005<0,05$ artinya Ho ditolak. Dapat disimpulkan bahwa terdapat perbedaan yang sangat signifikan terhadap nilai tindakan sebelum dan sesudah.

Penelitian ini sejalan dengan penelitian yang dilakukan oleh Satri (2014) tentang "Efektifitas Pendidikan Kesehatan Menggunakan Media Audio Visual Terhadap Perilaku Pencegahan Filariasis" yang menunjukkan bahwa terdapat peningkatan rata-rata tindakan sebelum dilakukan penyuluhan yaitu 12,25 dan standar deviasi 2,286 menjadi 13,50 dengan standar deviasi 1,884 setelah dilakukan penyuluhan dengan media audio visual. Hasil uji statistik didapatkan $\mathrm{p}$ value $=$ $0,000(\mathrm{p}<0,5)$ atau terdapat perbedaan signifikan rata-rata tindakan sebelum dan sesudah diberikan penyuluhan.

Setelah seseorang mengetahui objek atau stimulus, proses selanjutnya adalah memiliki atau bersikap terhadap stimulus atau objek tersebut. Manifestasi sikap tidak dapat dilihat langsung, namun harus teruwujud dalam suatu tindakan. Tindakan atau aksi dapat dilakukan dengan benar jika didahului oleh adanya pengetahuan yang baik dan sikap yang positif. Tanpa adanya dua domain tersebut, tindakan tentu akan mengarah kepada tindakan yang kurang baik. Namun banyak faktor lain yang juga mempengaruhi seseorang dalam bertindak. Adanya pengaruh lingkungan atau kebiasaan yang membuat seseorang bertindak tanpa didasari ilmu pengetahuan.

\section{KESIMPULAN}

Ada perbedaan perilaku masyarakat dalam pengelolaan sampah rumah tangga dengan pemberian penyuluhan dengan menggunakan media audio visual di Jorong Baringin Kenagarian Baringin Kabupaten Tanah Datar dengan nilai ( $\mathrm{p}=$ 0,0005). Diharapkan tenaga kesehatan untuk dapat memberikan edukasi dengan menggunakan metoda yang lebih kreatif kepada masyarakat, sehingga masyarakat dapat melakukan pengelolaan sampah RT dengan baik dan benar 


\section{E. UCAPAN TERIMAKASIH}

Terima kasih kami ucapkan kepada masyarakat di Jorong beringin yang telah berpartispasi dalam penelitian ini, serta bapak Jorong yang telah mengizinkan untuk melakukan pengambilan data dan memberikan penyuluhan.

\section{F. DAFTAR PUSTAKA}

Alfianur. 2015. Efektifitas Metode Ceramah Dengan Media Leaflet Terhadap Perubahan Perilaku Siswa Kelas 5 Dalam Pencegahan Penyakit Demam Berdarah (DBD). Fakultas Ilmu Kesehatan Universitas Borneo Tarakan.

Akbar Asfar, Asnaniar. 2018. Pengaruh Penyuluhan Kesehatan Terhadap Tingkat

Pengetahuan dan Sikap Tentang HIV / AIDS di SMP Baznas Provinsi Sulawesi Selatan. Journal off Islamic. Fakultas Kesehatan Masyarakat. Universitas Muslim Indonesia. Sulawesi Selatan.

Arifin H, 2018. Pengelolaan Sampah Pasar Kuraitaji Kecamatan Pariaman Selatan Kota Pariaman. Universitas Negeri Padang.

Anita Sri. 2017. Penyuluhan Dengan Media Audio Visual Meningkatkan Perilaku Hidup Bersih Sehat Anak Usia Sekolah. Urecol Proceeding. Program Studi Ilmu Keperawatan STIKES Cendekia Utama Kudus. Yogyakarta.

Asfar A, Asnaniar WOS, 2018. Pengaruh Penyuluhan Kesehatan Terhadap Tingkat Pengetahuan Dan Sikap Tentang Penyakit Hiv/Aids Di Smp Baznas Provinsi Sulawesi Selatan.

Badan Pusat Statistik, 2017. Statistik Lingkungan Hidup Indonesia 2017.

Badan Pusat Statistik Kabupaten Tanah Datar, 2018. Jumlah Penduduk Kabupaten Tanah Datar Tahun 2018. Kabuten Tanah Datar.

Budiyanto, Agus Krisno. 2016. Efektifitas Pemanfaatan Media Leaflet DalamMeningkatkan Pengetahuan dan Keterampilsn Mencuci Tangan Dengan Sabun. Prosiding. Fakultas Keguruan dan Ilmu Pendidikan. Universitas Muhammadiyah. Malang

Chandra B, 2006 Pengantar Ilmu Kesehatan Lingkungan. Jakarta EGC.

Darmawan G, 2013. Peran Unit Pelaksana Teknis (Upt) Kebersihan, Pertamanan, Dan Pemakaman (Kpp) Pada Dinas Pekerjaan Umum Dalam

Pengelolaan Sampah Di Kota Sangatta Kabupaten Kutai Timur.

Dagun, Save. 2006. Kamus Besar Ilmu Pengetahuan. Lembaga Kajian Kebudayaan Nusantara. Jakarta.

Dewi SP, Herawati L, Ganefati SP, 2014. Pengaruh Penyuluhan Dengan Metoda Demonstrasi Terhadap Peningkatan Pengetahuan Dan Tindakan Pengelolaan Sampah Ibu-Ibu Di Desa Cetan, Kecamatan Ceper, Kabupaten Klaten. Poltekkes Kemenkes Yogyakarta.

Dinas Lingkungan Hidup Sumbar, 2017. Volume sampah Sumatera Barat, https://sumbar.antaranews.com/berita/212579/volume-sampah-disumbar-2392-ton-per-hari.

Djunaidi, Angga, Much, 2017. Penentuan Alternatif Lokasi TPA (Tempat Pengelolaan Akhir) Sampah Di Kabupaten Wonogiri Dengan Menggunakan Metode Technique Of Order Preference By Similarity To Ideal Solution. (Skripsi). Universitas Muhammadiyah Surakarta. 
Fadillah A, 2015. Implementasi Peraturan Daerah Kota Samarinda Nomor 02 Tahun 2011 Tentang Pengelolaan Sampah (Studi Kasus Pada Dinas Kebersihan Dan Pertamanan Kota Samarinda).

Ismawati, Winda. 2018. Efektifitas Penggunaan Media Leaflet, Buku Saku, Video Untuk Meningkatkan Pengetahuan Pemberian Makanan Pendamping Air Susu Ibu (MP ASI) Di Desa Kenep Kecamatan Sukoharjo. Skripsi. Fakultas Ilmu Kesehatan. Universitas Muhammadiyah Surakarta. Jawa Tengah.

Kantor Lingkungan Hidup Kabupaten Tanah Datar, 2018. Perencanaan Teknis Dan Manajemen Persampahan. Tanah Datar. KLH Tanah Datar.

Kantor Wali Nagari Baringin, 2018. Profil Nagari Baringin tahun 2018. Kabupaten Tanah Datar.

Karo Yessi T Br, 2009. Pengelolaan Sampah Rumah Tangga Di Kelurahan Sidorame Timur Kecamatan Medan Perjuangan Kota Medan. (Skripsi). Universitas Sumatera Utara, Medan.

KementerianLingkungan Hidup RI, 2018, Sistem Informasi Pengelolaan Sampah, http:// sipsn.menlhk.go.id/?q=3a-data-umum.

Maghfiroh SA, Hardati P, Ariefin M, 2018. Pengaruh Penyuluhan Tentang Sampah Terhadap Pengetahuan, Sikap dan Perilaku Ibu Rumah Tangga (Anggota PKK) Dalam Mengelola Sampah Rumah Tangga Pada Permukiman Tradisional dan Permukiman Modern di Kelurahan Pudak Payung. Universitas Negeri Semarang.

Meidiana, Risma. 2018. Pengaruh Edukasi melalui Media Audio Visual terhadap Pengetahuan dan Sikap Remaja Overweight. Skripsi. Politeknik Kesehatan Kemenkes. Bengkulu

Musfirah, 2018. Pengaruh Penyuluhan Terhadap Pengetahuan Dan Intensi Perilaku Pengelolaan Sampah Konsep 3r Siswa Kelas X Sekolah Menengah Kejuruan, Yogyakarta, Indonesia. Fakultas Kesehatan MasyarakaUniversitas Ahmad Dahlan.

Notoatmodjo S, 2007. Promosi Kesehatan Dan Ilmu Perilaku. Jakarta. Rineka Cipta. Notoatmodjo S, 2010. Metedologi Penelitian Kesehatan. Jakarta. Rineka Cipta.

Nurafiyani, Ifa, Huriah T, 2010. Pengaruh Penyuluhan Tentang Pengelolaan Sampah Rumah Tangga Terhadap Tingkat Pengetahuan Masyarakat Rt13 Serangan Kelurahan Notoprajan Kecamatan Ngampilan Yogyakarta. Sekolah Tinggi Ilmu Kesehatan Aisyiyah, Yogyakarta.

Octavia, Windy. 2015. Peni8ngkatan Pengetahuan, Sikap dan Tindakan Remaja Laki-laki di SMKN 4 Umbul Harjo Tentang Antibiotika dengan Metode Cara Belajar Insan Aktif (CBIA). Skripsi. Fakultas Farmasi Universitas Sanata Dharma. Yogyakarta.

Our World in Data, 2015, Sampah Plastik Dunia dalam Angka,hhtps://internasional.kompas/read/2018/11/21/18465601/samp ah-plastik-dunia-dalam-angka.

Panghiyangani, Roselina, dkk. 2018. Efektivitas Metode Penyuluhan Kesehatan Terhadap Peningkatan Pengetahuan, Sikap Dan Tindakan Tentang Pencegahan Keputihan Patalogis. Program Studi Magister Ilmu Kesehatan Masyarakat Fakultas Kedokteran Universitas Lambung Mangkurat. Kalimantan Selatan. 
Putri, Anisha Tiara. 2017. Efektifitas Media Audio Visual dan Leaflet Terhadap Peningkatan Pengetahuan, Sikap dan Tindakan Tentang Pencegahan Penyakit Gastritis Pada Santriwati di Pondok Pesantren Hidayatullah. Jurnal Ilmiah. Fakultas Kesehatan Masyarakat, Universitas Halu Oleo. Kendari

Ramon A, Afriyanto, 2015. Karakteristik Penanganan Sampah Rumah Tangga Di Kota Bengkulu.

Saban, Saharyah. 2017. Efektifitas Media Video dan Leaflet Terhadap Peningkatan Pengetahuan Tentang Anemia Siswi SMAN 2 Ngaglik. Laporan Tugas Akhir. Fakultas Ilmu Kesehatan. Universitas 'Aisyiyah. Yogyakarta.

Sadiman, Arief. 2006. Media Pendidikan, Pengembangan dan Pemanfaatannya. PT. Raja Grafindo Persada. Jakarta

Satri, dkk. 2014. Efektifitas Pendidikan Kesehatan Menggunakan Media Audiovisual Terhadap Perilaku Pencegahan Filariasis. JOM PSIK. Program Studi Ilmu Keperawatan. Universitas Riau.

Slamet JS, 2013. Kesehatan Lingkungan. Yogyakarta. Gadjah Mada University Press.

Sulaeman, Amir. 1985. Media Audio Visual Untuk Pengajaran, Penerangan dan Penyuluhan. PT. Gramedia. Jakarta

Tarigan. 2016. Efektivitas Promosi Kesehatan dengan Media Leaflet dan Media Video terhadap Pengetahuan dan Sikap Remaja tentang HIV/AIDS di SMA Negeri 1 Berastagi Tahun 2016. Tesis. Fakultas Kesehatan Masyarakat. Universitas Sumatera Utara.

Tewal FB, Ratag B, 2012. Pengaruh Penyuluhan Terhadap Perilaku Masyarakat Dalam Pengelolaan Sampah (Studi Kasus Di Desa Raranon, Kecamatan Langowan Barat, Kabupaten Minahasa). Fakultas Kesehatan Masyarakat Universitas Sam Ratulangi Manado.

Undang-Undang Republik Indonesia Nomor 18 Tahun 2008 Tentang Pengelolaan Sampah.

Wardhana, WA, 2004. Dampak Pencemaran Lingkungan. Yogyakarta. Andi Yogyakarta.

Waryana, 2016. Promosi Kesehatan Penyuluhan Dan Pemberdayaan Masyarakat. Nuha Medika. Yogyakarta.

Widiastuti VA, Yuniastuti A, 2017. Analisis Hubungan Sikap Perilaku Pengelolaan Sampah dengan Gejala Penyakit pada Masyarakat di TPI Kota Tegal. Universitas Negeri Semarang.

Widiyanto AF, Gamelia E, Kurniawan A, 2017. Efektivitas Pelatihan Tentang Pengolahan Sampah Padat Organik Dalam Meningkatkan Pengetahuan, Sikap Dan Keterampilan Ibu Dalam Mengolah Sampah. Universitas Jenderal Soedirman 